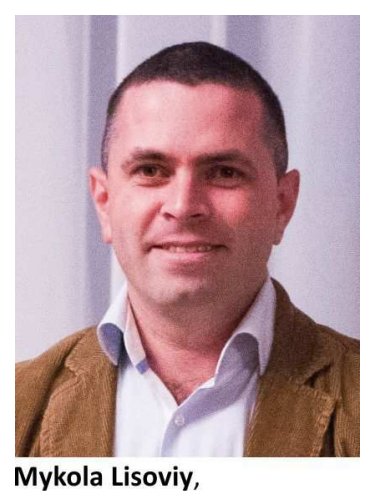

Mykola Lisoviy, PhD, Associate Professor, Email: lisovyj82@gmail.com

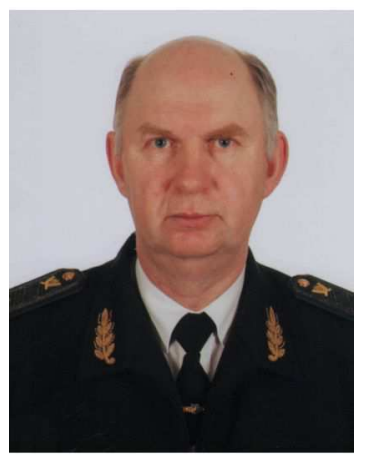

Mykola Guz,

Dr. Hab., Professor,

Email:mguz@ukr.net

\section{PROSPECTS FOR GENETIC RESOURCES REPRODUCTION OF THE MAIN FOREST-FORMING GYMNOSPERM SPECIES IN UKRAINE BY BREEDING IN VITRO}

Effective breeding of the main forest-forming gymnosperm species of Ukraine (Pinus sylvestris L., Larix decidua Mill., Abies alba Mill. And Risea abies (L.) Karsten), which are of significant value for Forestry and Landscape Architecture, is a very important task. The solution to this task may be the use of modern methods of reproduction, namely in vitro micro-cloning. Decontamination of explants was conducted applying the following sterilizing agents in different concentrations and in different combinations: tap water $\left(\mathrm{H}_{2} \mathrm{O}\right)$ with a detergent; Medical ethanol $\left(\mathrm{C}_{2} \mathrm{H}_{5} \mathrm{OH}\right)$; sodium hypochlorite $(\mathrm{NaClO})$; silver nitrate $(\mathrm{Ag}$ $\mathrm{NO}_{3}$ ). To prevent internal infections, a $0.1 \%$ "Imaninum" antibiotic was applied. To initiate explants, the following nutrient media were used: Murashige and Skoog (MS), Risser and White (RW) and Litvay (LM), which were modified with phytohormones: 2,4-D; NAA; IBA and BAP. Rooting of the obtained clones was performed on $1 / 2 \mathrm{MS}$ and 1/2 LM media, supplemented with auxin (2,4-D; NAA IAA and the IBA). Adaptation of clones to ex vitro conditions was exercised in the sod soil and sand (1:1) and sod soil with peat and sand (1:1:1). The following sterilization results were observed in: Pinus sylvestris L. - 98, Larix decidua Mill. - 96 Abies alba Mill. - 98 and Risea abies (L.) Karsten - $97 \%$ of aseptic explants. The proper selection of nutrient medium resulted in high initiation of: Pinus sylvestris L. - 92, Larix decidua Mill. - 95 Abies alba Mill. - 94 and Risea abies (L.) Karsten - 95\%. The importance of the auxin and cytokinin presence in the medium at this stage should be noted. Rhizogenesis results of the study species are as follows: Pinus sylvestris L. - 86, Larix decidua Mill. - 91 Abies alba Mill. - 93 and Risea abies (L.) Karsten $-89 \%$. It is established that injection of IAA to the medium is necessary, since the number of rooted clones was only increasing during all scenarios. The largest number of adapted clones was observed on the substrate of sod soil with peat and sand, except for the plant-regenerants of Larix decidua, where the substrate of the sod soil and sand had given a better result. Application of in vitro breeding for the study species is very promising, since satisfactory results were obtained at all stages. A further study of cultivation phase is necessary, since it will enable to determine the rate and stage of adaptation to in vivo conditions.

Keywords: forest-forming species; breeding; in vitro; explant; decontamination; initiation; rhizogenesis; adaptation.

\section{Introduction}

The most common forest-forming gymnosperm species in Ukraine are the following four species: common pine (Pinus sylvestris L.), which forms over $30 \%$ of forests in our country and is characterized by high frost hardiness, drought-resistance, relative nonexactingness to soil fertility and resistance to urban conditions (Butenko, 1964; Kohno, et al., 2001; Lisovyj, 2016); European larch (Larix decidua Mill.) has been the object of forest culture practice in Ukraine more than 200 years, which, when introduced into artificial forest plantations, is able to more quickly generate large timber resources and in the future can become a significant reserve for increasing productivity of our forests (Gavrylyuk, Guz \& Lisovyj, 2013a, 2013b; Debrynyuk, 1993; Debrynyuk \& Belelya, 2012; Debrynyuk, 2014; Debrynyuk, 2010); silver fir (Abies alba Mill.) is a valuable native species in Ukraine, which acts in the Carpathians as a type-forming and climatic admixture which, by its productivity, is not inferior to spruce (Golubets, Gavrusevych \& Zahaykevych, 1988); fir spruce (Picea abies (L.) Karsten) is widely used in forest cultivation within the area of its natural distribution (Golubets, 1978; Pravdin, 1975). There is evidence of high productivity of spruce stands outside the ranges of spruce natural distribution, where, under optimal conditions of growth, spruce is a sufficiently fast-growing and highly productive species and is able to accumulate significant volumes of wood for relatively short periods of time (Debrynyuk, 1995; Pokhylchenko, 2011). It is worth mentioning that all the above-mentioned species, without exception, are characterized by significant genetic polymorphism and, therefore, are promising in terms of landscape gardening (Gavrylyuk, Guz \& Lisovyj, 2013a, 2013c; Gozhan, Guz \& Grechanyk, 2012; Kohno, et al., 2001; Lisovyj, 2016; Lisovyj, Guz \& Kanteruk, 2012; Lisovyj, 2013; Shlapak \& Nebikov, 2011).

Цитування за ДСту: Lisoviy M. M., Guz M. M. Prospects for genetic resources reproduction of the main forest-forming gymnosperm species in Ukraine by breeding in vitro. Науковий вісник НЛтУ України. 2017. Вип. 27(8). С. 70-75.

Citation APA: Lisoviy, M. M., \& Guz, M. M. (2017). Prospects for genetic resources reproduction of the main forest-forming gymnosperm species in Ukraine by breeding in vitro. Scientific Bulletin of UNFU, 27(8), 70-75. https://doi.org/10.15421/40270810 
Taking into account the above-mentioned characteristics of the study species, in particular, their importance for forestry and landscaping in Ukraine, we can conclude that it is relevant and necessary to improve modern methods of production of valuable-breeding planting material that can provide for reproduction of specific genotypes (plus trees, ornamental varieties, etc.). A solution to the problem could be microcloanal reproduction in vitro which has the following advantages: high coefficient of reproduction; plants sanitation: removal of viruses and pathogenic microorganisms; acceleration of selection process; propagation of plants which hardly or do not propagate at all by other methods; renovation of old species individuals, etc. (Butenko, 1986; Butenko, 1964; Butenko, 1986; Musiyenko \& Panyuta, 2005). Some scientists hold to the idea that micro- cloning provides a possibility of accelerating the rate of perennials reproduction by 3-4 times (Bugara \& Bugara, 2003; Butenko, 1986; Katayeva \& Butenko, 1983).

Thus, the research object are genetic resources of the main forest-forming gymnospermspecies of Ukraine obtained by in vitro reproduction, while the subject of research are the processes of microclonal reproduction that enable the production of planting material of the study species.

\section{Literature review}

To the study of prospects for applying method of tissue culture for reproduction of study species is devoted a number of works both foreign and Ukrainian scientists. In particular, V. V. Shlapak and M. V. Nebikov (2011 investigated the peculiarities of seed propagation of common pine in vitro conditions (Shlapak \& Nebikov, 2011).For callusogenesis of common pine, I. P. Filippova (2010) recommends to use as explants germinating seedlings and mature zygotic embryos passaged onto the medium S MS, modified by addition of 2,4-D (2 mg/l) and 6-BA (1 mg/l) (Filipova, 2010). U. Andersone and G. Ievinsh $(2002,2008)$ investigated the effects of harvesting season and cold storage of buds for explants harvesting on their morphogenesis and $\mathrm{pH}$ of the nutrient medium at microcloning of common pine (Andersone, n.d.; Andersone, 2008; Becwar, Noland \& Wyckoff, 1989). V. G. Lebedev and K. A. Shestibratov (2011) developed a method for microclonal reproduction of the study species of two-week-old germinating seedlings, which include buds induction, multiplication, rooting and adaptation of the obtained clones (Lebedev \& Shestibratov, 2011).

For microclonal reproduction of European larch, J. Ziauka and S. Kuusienл (2006) used as explants small segments of young shoots with auxiliary buds taken from 40year-old trees. It was found that abscisic acid negatively affected the organogenesis of vegetative buds. Auxins also suppressed the growth of explants on the 25th day of observation, but on the 75th day there was again a tendency for developing shoots. The most positive effect of cytokinins was observed in explants cultivated in the darkness (Ziauka \& Kuusienl, 2006). V. Chalupa (2004) investigated the influence of the explants source, parent tree age, the composition of the nutrient medium and phytohormones on the breeding of European larch in conditions in vitro. The rooting variability of regenerant plants varied among clones within 47-83\% (Chalupa, 2004). A. M. Diner et al (1986) used as explants juvenile tissue from young seedlings as well as European larch seeds, the initiation of which was carried out within two weeks in the BLG medium with adding cytokinin (BA). In a 16-week time of cultivation, sho- ots were formed (more than $1 \mathrm{~cm}$ ), some of which were rooted (Diner, Strickler \& Karnovsky, 1986).

K. Nawrot-Chorabik (2008) was using as explants megagametophytes, zygotic embryos and fir needles to get embryogeneous callus. The best results were obtained on the nutrient medium $\mathrm{SH}$, and the highest percentage of sterilized explants was obtained using the solution of $10 \%$ $\mathrm{NaOCl}$ (Nawrot-Chorabik, 2008). As described in the work by K. Szczygiel and J. Kowalczyk (2001), mature embryos were cultivated in different nutrient media for the somatic embryogenesis Abies alba Mill.,. The induction frequency of embryos was 1.0-29.4\%. Germination of somatic embryos was at the level of 69-79\% (Szczygiel \& Kowalczyk, 2001). J. Krajnakova et al. (2013) studied the influence of the parent tree, the harvesting period and the cryoprotection of fir explants on their micropropagation ability. Initiation frequency was observed from 1.7 to $16.6 \%$. The embryogenic cultures were saved for 6 years, after that 4 of the 12 embryogenic cell lines were viable, and embryo regeneration was observed from two lines (Krajtbkovb, Bertolini \& Gcmcry, 2013).

A number of works by M. M. Guz, R. M. Grechanyk and M. Ya. Gozhan (2012-2015) are devoted to microcloning of some species and cultivars of the genus Picea. The success rate of sterilization of the study taxons was $66.7 \%$. In $26.7-46.7 \%$ of explants, there were noted an adventitious shoots formation, and rhizogenesis occurred in 46.7$70.0 \%$ of clones (Gozhan, 2014; Gozhan \& Lisovyj, 2015; Grechanyk, Gozhan \& Guz, 2012). K. Szczygie et al. (2007) conducted a study on somatic embryogenesis of several coniferous taxons, including fir spruce, using seeds of different geographical origin. The best development of embryogenic callus was observed using zygotic embryos as explants (23-31\%) (Szczygie, Hazubska-Przyby \& Bojarczuk, 2007). M. R. Becwar et al. (1989) conducted a study of three stages of regeneration of fir spruce trees using seeds as explants. In the experiments, only $3 \%$ of immature embryos developed to the stage of cotyledons. In general, viable plants were obtained from $29 \%$ of somatic embryos (Becwar, Noland \& Wyckoff, 1989). L. H. Mo and S. von Arnold (1991) obtained embryogenetic structures in vitro from zygotic embryos of Picea abies, which were cultivated in a nutrient medium of $9.0 \mathrm{mM} 2.4-\mathrm{D}$ and $4.4 \mathrm{mM}$ BA. On average, $39 \%$ explants formed embryonic structures. The proliferation of these structures was noted in $10-15 \%$ cases. It has been established that the age of the initial explants did not affect the experimental results (Mo \& von Arnold, 1991).

Analysing literary sources, we can conclud that there is a need to improve the methods of reproduction of study species by microcloning, in particular, by activating the growth of the axillary meristems, which excludes the possibility of mutations and provides reproduction of clones with a genetically identical genotype.

\section{Material and methods}

The studies on in vitro reproduction of the study species were carried out in the laboratory of tissue culture at the Forestry and Forest Selection Department of UNFU according to generally accepted methods in biotechnology (Butenko, 1986; Butenko, 1964; Katayeva \& Butenko, 1983) using necessary special equipment.

In general, the whole micropropagation process consisted of the following main stages: choosing the donor- 
plant and obtaining the explants; sterilization of initial explants, initiation of explants growth, rhizogenesis of obtained mericlones and adaptation of rooted plants. Lateral and terminal vegetative buds were used as initial explants, which were taken from young plants of investigated species that were grown from seeds (5-7 years old).

All the activities were carried out in maximum sterile conditions (Grechanyk, Guz \& Oleksiychenko, 2011; Shlapak \& Nebikov, 2011). Therefore, all the surfaces of the laboratory facilities and equipment were treated with a $96 \%$ ethanol, and before each experiment, the premises were being sterilized for 1.5-2.0 hours using ultraviolet bactericidal lamps. The instruments were disinfected by dry heating in a drying chamber at a temperature of $160-180{ }^{\circ} \mathrm{C}(1.0-$ 1.5 hours), and before each manipulation with the explants passage, they were treated with a $96 \%$ ethanol and flamed.

Decontamination of the plant material was carried out with the following sterilizing agents of different concentrations and in their various combinations: water $\left(\mathrm{H}_{2} \mathrm{O}\right)$ with detergent, medical ethyl spirit $\left(\mathrm{C}_{2} \mathrm{H}_{5} \mathrm{OH}\right)$, sodium hypochloride $(\mathrm{NaClO})$, silver nitrate $\left(\mathrm{AgNO}_{3}\right)$. To remove the used reagents, the explants were thoroughly rinsed three times with sterile distilled water after using them. To prevent internal infections, a $0.1 \%$ aqueous solution of the antibiotic "Imaninum" was used. Each initial explant was treated with this substance directly before the passage. After sterilization, the explants were passaged into nuantrient medium following the prescription of Murashige and Skoog (MS) without phytohormones and monitored for 10-15 days.

For the stage of explants initiation, three basic nutrient media were used according to the prescriptions: Murashige and Skoog medium (MS), Risser and White medium (RW) and Litvay medium (LM), which were modified with the following phytohormones: 2,4-D; NAA; IBA and BA in different combinations and concentrations (Butenko, 1964; Lisovyj, Guz \& Kanteruk, 2012; Lisovyj, 2013; Musiyenko $\&$ Panyuta, 2005). The rooting process of the obtained clones was carried out in MS and LM media with twice reduced concentration of mineral salts which were supplemented only by auxins (2,4-D, NAA, IAA and IBA) that stimulate root formation.

The cultivation of explants at all stages of microcloning was carried out in a cultural room at a temperature of 20$22{ }^{\circ} \mathrm{C}$, at a relative humidity of $30-35 \%$ and during a 16 hour photoperiod (2.8-3.0 kLx).

The adaptation of regenerant plants to conditions ex vitro was carried out in soddy soil with sand and peat (1:1:1) which were sterilized at a temperature about $90{ }^{\circ} \mathrm{C}$ for 1.5 hours, with substrates preliminary treated with a $0.5 \%$ potassium manganese. The clones were placed into controlled conditions with initial air humidity of 95-100\% and a temperature of $22^{ \pm 1}{ }^{\circ} \mathrm{C}$. The adaptation was carried out gradually over 30-35 days, reducing the air humidity by $5^{ \pm 1} \%$ and the temperature by $0.5^{ \pm 0.1}{ }^{\circ} \mathrm{C}$ every 5 days.

\section{Results and discussion.}

Observations on the results of decontamination of the initial explants were carried out within 10-15 days. After that, they were classified into the following categories: contaminated (infected); necrotic (damaged by chemical agents); aseptic (sterile) (Table 1, Figure 1).

Table 1. Results of explants decontamination of the investigated species

\begin{tabular}{|c|c|c|c|c|c|}
\hline \multirow{2}{*}{ No. } & \multirow{2}{*}{$\begin{array}{c}\text { Wood } \\
\text { species }\end{array}$} & \multirow{2}{*}{ Decontamination scheme } & \multicolumn{3}{|c|}{ Received explants, $\%$} \\
\hline & & & Contaminated & Necrotic & Aseptic \\
\hline 1 & P. sylvestris & $\begin{array}{c}\mathrm{C}_{2} \mathrm{H}_{5} \mathrm{OH}(96 \% ; 10 \mathrm{sec} .)+\text { running } \mathrm{H}_{2} \mathrm{O} \text { with detergent }+\mathrm{NaClO} \\
(20 \% ; 5 \text { min. })+\mathrm{C}_{2} \mathrm{H}_{5} \mathrm{OH}(70 \% ; 10 \mathrm{sec} .)+\mathrm{AgNO}_{3}(0,2 \% ; 5 \text { min. })\end{array}$ & 2 & - & 98,0 \\
\hline 2 & L. decidua & $\begin{array}{c}\mathrm{C}_{2} \mathrm{H}_{5} \mathrm{OH}(70 \% ; 10 \mathrm{sec} .)+\text { running } \mathrm{H}_{2} \mathrm{O} \text { with detergent }+\mathrm{NaClO} \\
(50 \% ; 5 \text { min. })+\mathrm{C}_{2} \mathrm{H}_{5} \mathrm{OH}(70 \% ; 10 \mathrm{sec} .)+\mathrm{AgNO}_{3}(0,2 \% ; 10 \text { min. })\end{array}$ & 4 & - & 96,0 \\
\hline 3 & A. alba & $\begin{array}{c}\mathrm{C}_{2} \mathrm{H}_{5} \mathrm{OH}(50 ; \% 10 \text { sec. })+\text { running } \mathrm{H}_{2} \mathrm{O} \text { with detergent }+\mathrm{NaClO} \\
(10 \% ; 7 \text { min. })+\mathrm{C}_{2} \mathrm{H}_{5} \mathrm{OH}(50 \% ; 10 \mathrm{sec} .)+\mathrm{AgNO}_{3}(0,1 \% ; 10 \text { min. })\end{array}$ & - & 2 & 98,0 \\
\hline 4 & P. abies & $\begin{array}{c}\mathrm{C}_{2} \mathrm{H}_{5} \mathrm{OH}(96 \% ; 5 \text { sec. })+\text { running } \mathrm{H}_{2} \mathrm{O} \text { with detergent }+\mathrm{NaClO}(30 \% ; 7 \text { min. }) \\
+\mathrm{C}_{2} \mathrm{H}_{5} \mathrm{OH}(70 \% ; 5 \mathrm{sec} .)+\mathrm{AgNO}_{3}(0,1 \% ; 7 \text { min. })\end{array}$ & 1 & 2 & 97,0 \\
\hline
\end{tabular}

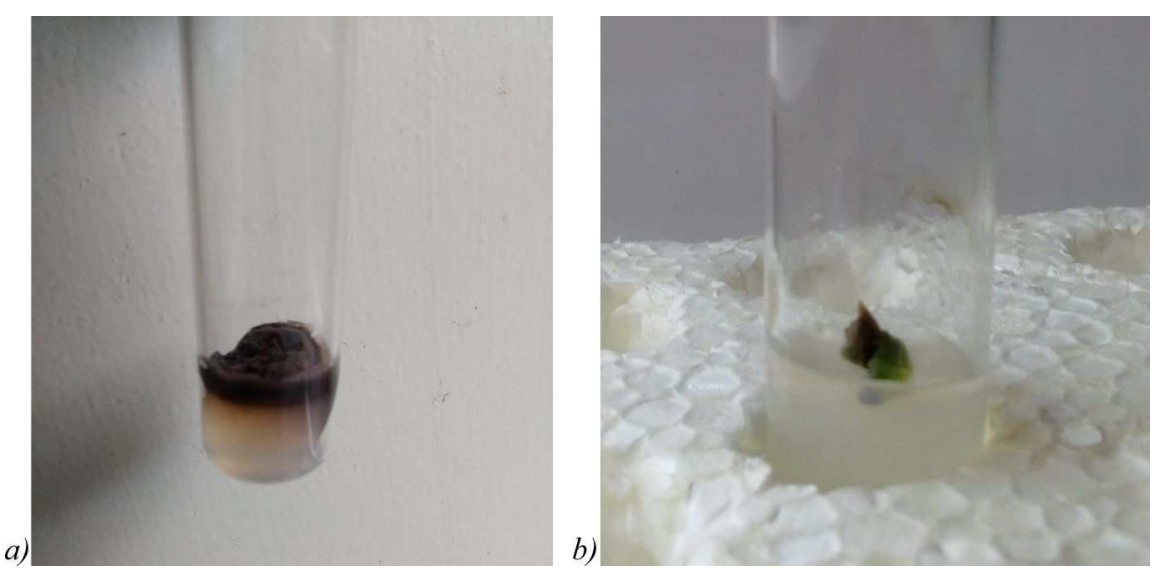

Figure 1. Contaminated explant of European larch (a); Aceptic explant of common pine (b)

In Table 1, presented are sterilization schemes, the use of which provided the largest number of aseptic viable explants.

The conducted studies made it possible to conclude that it is necessary first to treat explants (all without exception) with ethanol.Otherwise, a significant number of contamina- ted explants was observed, as in the case of removal of some chemical agents from the scheme. At the same time the application of high concentration sterilizers triggered the appearance of necrotic vegetative material (Figure 1). Monitoring the process of explants initiation was carried out during a period of 45-50 days. After that, initiated were 
considered those that increased their linear size in three or more times (Table 2, Figure 2).

Table 2. Results of explants initiation of investigated species

\begin{tabular}{|c|c|c|c|}
\hline No & $\begin{array}{c}\text { Wood } \\
\text { species }\end{array}$ & Composition of nutrient medium & $\begin{array}{c}\text { Initiated } \\
\text { explants, } \\
\%\end{array}$ \\
\hline 1 & $\begin{array}{c}\text { P. } \\
\text { sylvestris }\end{array}$ & $\begin{array}{c}\mathrm{MS}+2,4-\mathrm{D}(0,2 \mathrm{mg} / \mathrm{l})+\mathrm{NAA} \\
(0,5 \mathrm{mg} / \mathrm{l})+\mathrm{BA}(0,1 \mathrm{mg} / \mathrm{l})\end{array}$ & 92,0 \\
\hline 2 & L. decidua & $\begin{array}{c}\mathrm{MS}+2,4-\mathrm{D}(0,1 \mathrm{mg} / \mathrm{l})+\mathrm{IBA} \\
(0,3 \mathrm{mg} / \mathrm{l})+\mathrm{BA}(0,2 \mathrm{mg} / \mathrm{l})\end{array}$ & 95,0 \\
\hline 3 & A. alba & $\begin{array}{c}\mathrm{LM}+\mathrm{NAA}(0,2 \mathrm{mg} / \mathrm{l})+\mathrm{IBA} \\
(0,3 \mathrm{mg} / \mathrm{l})+\mathrm{BA}(0,1 \mathrm{mg} / \mathrm{l})\end{array}$ & 94,0 \\
\hline 4 & P. abies & $\begin{array}{r}\mathrm{LM}+2,4-\mathrm{D}(0,3 \mathrm{mg} / \mathrm{l})+\mathrm{NAA} \\
(0,1 \mathrm{mg} / \mathrm{l})+\mathrm{BA}(0,1 \mathrm{mg} / \mathrm{l})\end{array}$ & 95,0 \\
\hline
\end{tabular}

a)
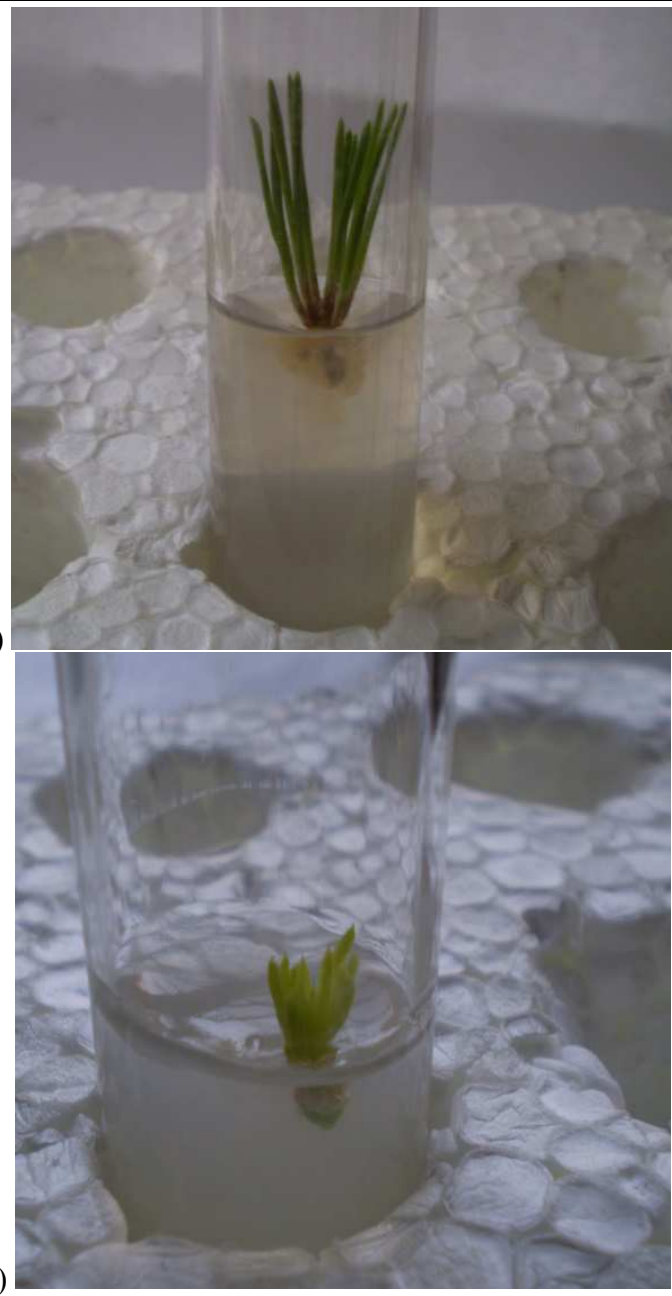

Figure 2. Initiated explants: a) common pine; b) fir spruce

The data presented in Table 2 indicates that the correct selection of the optimum nutrient medium is capable to provide sufficient high rates of initiation of the investigated species, in particular: $92.2 \%$ for common pine; European Larch $-95.0 \%$; silver fir $-94.0 \%$, and fir spruce $-95.0 \%$. It should be noted that there is a need for auxins and cytokinins to be present in the nutrient medium.

For rooting of initiated shoots, they were passaged into $1 / 2 \mathrm{MS}$ and 1/2 LM nutrient medium, since RW medium did not produce positive results in previous studies (Table 3, Figure 3).

Having conducted experiments on rhizogenesis of the study gymnosperm species, it could be conclude that it is necessary that nutrient medium should include phytohormone IAA, which in all variants increased the number of clones that formed the roots. Transferring of obtained clones into conditions ex vitro is an important step on which the final result of microclonal reproduction depends.

Table 3. Results of explants rhizogenesis of investigated species

\begin{tabular}{|c|c|c|c|}
\hline No. & $\begin{array}{c}\text { Wood } \\
\text { species }\end{array}$ & Composition of nutrient medium & $\begin{array}{c}\text { Explants } \\
\text { rooting, \% }\end{array}$ \\
\hline 1 & P. sylvestris & $\begin{array}{r}1 / 2 \mathrm{MS}+\mathrm{NAA}(0,5 \mathrm{mg} / \mathrm{l})+\mathrm{IAA} \\
(1,0 \mathrm{mg} / \mathrm{l})\end{array}$ & 86,0 \\
\hline 2 & L. decidua & $\begin{array}{r}1 / 2 \mathrm{MS}+\mathrm{IAA}(0,1 \mathrm{mg} / \mathrm{l})+\mathrm{IBA} \\
(0,5 \mathrm{mg} / \mathrm{l}) ; \\
1 / 2 \mathrm{LM}+2,4-\mathrm{D}(0,3 \mathrm{mg} / \mathrm{l})+\mathrm{IAA} \\
(0,1 \mathrm{mg} / \mathrm{l})+\mathrm{IAA}(0,2 \mathrm{mg} / \mathrm{l})\end{array}$ & 91,0 \\
\hline 3 & A. alba & $\begin{array}{r}1 / 2 \mathrm{MS}+2,4-\mathrm{D}(0,5 \mathrm{mg} / \mathrm{l})+\mathrm{IAA} \\
(0,5 \mathrm{mg} / \mathrm{l})\end{array}$ & 93,0 \\
\hline 4 & P. abies & $\begin{array}{r}1 / 2 \mathrm{LM}+2,4-\mathrm{D}(0,2 \mathrm{mg} / \mathrm{l})+\mathrm{IBA} \\
(0,2 \mathrm{mg} / \mathrm{l})+\mathrm{IAA}(0,1 \mathrm{mg} / \mathrm{l})\end{array}$ & 89,0 \\
\hline
\end{tabular}

a)

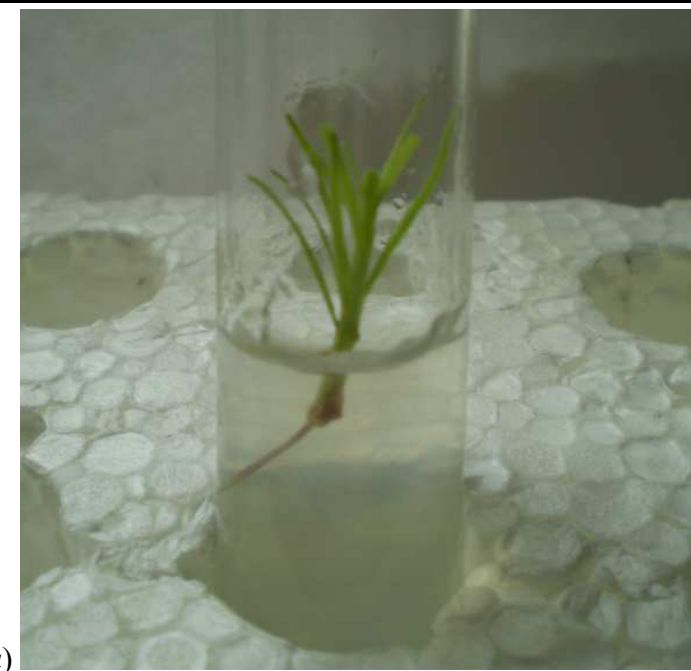

b)

Figure 3. Rooted explants: a) European Larch; b) silver fir

The adaptation of plants-regenerants was carried out under controlled conditions of the culture room. After a 35-day time, records were kept of visually viable plants (Table 4).

Table 4. Results of adaptation of investigated clones to ex vitro conditions

\begin{tabular}{|c|c|c|c|c|c|}
\hline \multirow{2}{*}{ No. } & Substrat & \multicolumn{4}{|c|}{ Adapted clones, \% } \\
\cline { 3 - 6 } & P. sylvestris & $\begin{array}{c}\text { L. de- } \\
\text { cidua }\end{array}$ & A. alba & P. abies \\
\hline 1 & Soddy soil + sand & 48,0 & 90,0 & 54,0 & 62,0 \\
\hline 2 & $\begin{array}{c}\text { Soddy soil + sand }+ \\
\text { peat }\end{array}$ & 89,0 & 67,0 & 87,0 & 88,0 \\
\hline
\end{tabular}

The obtained results indicate that a greater number of adapted clones of the study species was observed on substrate No. 2 (soddy soil + sand + peat), with the excepti- 
on of plant-regenerants of European larch, where the first experimental version (soddy soil + sand) was the best.

\section{Conclusions}

Analysing the results of experimental investigation gives grounds to assert the perspectiveness of using the in vitro propagation method for the most widespread forest-forming species in Ukraine, since the obtained results are satisfactory at all stages: decontamination - 96.0-98.0 \%; initiation - 92.0-95.0\%; rhizogenesis - 86.0-93.0\% and adaptation to the ex vitro conditions $-87.0-90.0 \%$ for the corresponding tree species.

However, in order to make a final decision on the application of this method of vegetative propagation in the practice of forest-culture production, it is necessary to conduct additionally an investigation on the stage of shoots multiplication, which will enable to determine the reproduction coefficient of the source plant material for each particular species, and the stage of adaptation of obtained clones to in-vivo conditions.

\section{References}

Andersone, U., \& Ievinsh, G. (2002). Changes of Morphogenic Competence in Mature Pinus sylvestris L. Buds in vitro. Anals of botany, 90(2), 293-298. https://doi.org/10.1093/aob/mcfl76

Andersone, U. \& Ievinsh, G. (2008). Medium $\mathrm{pH}$ affects regeneration capacity and oxidative enzyme activity of Pinus sylvestris in tissue culture. Acta Universitatis Latviensis, Biology, 745, 25-35

Becwar, M. R., Noland, T. L., \& Wyckoff, J. L. (1989). Maturation, germination, and conversion of norway spruce (Picea abies L.) somatic embryos to plants. In vitro Cell Dev. Biol, 25, 575-579.

Bugara, A. M., \& Bugara, I. A. (2003). Ispolzovanie metodov biotehnologii dla razmnozhenia rastenij i sohranenia genofonda. Ecosistemy Kryma, ih optimizacia $i$ ohrana: tematichnyi sbornik nauchnyh rabot, 13, 14-20. [in Russian].

Butenko, R. G. (1964). Kultura izolirovanyh tkanej i fiziologia morfogeneza rastenij. Moscow: Nauka, 272 p. [in Russian].

Butenko, R. G. (1986). Kletochnye tehnologii dla poluchenia ekonomicheski vazhnyh veshchestv rastitelnogo proizhozhdenija. Cultura kletok rastenij biotehnologia, 4, 3-20. Moscow: Nauka. [in Russian].

Butenko, R. G. (1986). Kultura kletok rastenij i biotehnologia. Moscow: Nauka, 285 p. [in Russian].

Chalupa, V. (2004). In vitro propagation of European larch (Larix decidua MilL.). Journal of Forestry Science, 50(12), 553-558.

Debrynyuk, Yu. M. (1993). Perspectyvy vykorystannya modryny yevropeyskoi dlya pidvyshchennya produktyvnosti lisiv Ukrainy. Ukrainskyi lis, 2, 36-37. [in Ukrainian].

Debrynyuk, Yu. M. (1995). Shchodo osoblyvostey stvorennya ta docilnosti vyroshchuvannya yalyny yevropeiskoi za mezhamy ii pryrodnoho arealu. Lis. zhurn, 3, 8-10, Lviv: NLTU Ukrainy. [in Ukrainian].

Debrynyuk, Yu. M. (2010). Tehnologichni aspecty stvorennya i vyroshchuvannya plantaciynyh lisovyh kultur za uchastyu modryny ta yalyny u Zahidnomu regioni Ukrainy. Naukovi praci Lisivnychoi akademii nauk Ukrainy: zb. nauk. prac, 8, 59-64. Lviv: NLTU Ukrainy. [in Ukrainian].

Debrynyuk, Yu. M. (2014). Rozpovsyudzhennya ta formove riznomayittya Larix decidua Mill. Pratsi naukovoho tovarystva im. Shevchenka. Ekolohichnyi zbirnyk, 39, 181-192. [in Ukrainian].

Debrynyuk, Yu. M., \& Belelya, S. O. (2012). Poshyrennya modryny u lisovyh nasadzhennyah Ukrainy. Naukovi praci Lisivnychoi akademii nauk Ukrainy: zb. nauk. prac, 10, 55-65. Lviv: NLTU Ukrainy. [in Ukrainian].

Diner, A. M., Strickler, A., \& Karnovsky, D. F. (1986). Ininiation, elongation, and remultiplication of Larix decidua micropropagules. New Zealand Journal of Forestry Science, 16(3), 306-318.

Filipova, I. P. (2010). Adventivnoye pochkoobrazovanije i kallusogenez $u$ sibirskih vidov hvoinyh $v$ kulture in vitro. Retrieved from: http://www. dissercat. com/content/adventivnoe-pochkoobrazova- nie-i-kallusogenez-u-sibirskikh-vidov-khvoinykh-v-kulture-vitro. [in Russian].

Gavrylyuk, V. M., Guz, M. M., \& Lisovyj, M. M. (2013a). Osoblyvosti shcheplennya morfologichnyh form modryny yevropeyskoi. Scientific Bulletin of UNFU, 23(12), 53-58. [in Ukrainian].

Gavrylyuk, V. M., Guz, M. M., \& Lisovyj, M. M. (2013b). Pidvyshchennya shozhosti nasinnya modryny yevropejskoi stymulyatoramy rostu. Scientific Bulletin of UNFU, 23(15), 44 -49. [in Ukrainian].

Gavrylyuk, V. M., Guz, M. M., \& Lisovyj, M. M. (2013c). Polimorfizm modryny yevropejskoi ta perspektyvy vykorystannya jiji $\mathrm{v}$ ozelenenni. Scientific Bulletin of UNFU, 23(3), 15-20. [in Ukrainian].

Golubets, M. A. (1978). Yelniki Ukrainskih Karpat. Kyiv : Nauk. dumka, 262 p. [in Russian].

Golubets, M. A., Gavrusevych, A. N., \& Zahaykevych, I. K. (1988). Pryroda Ukrajinskyh Karpat. Kyiv: Naukova dumka, 208 p. [in Ukrainian].

Gozhan, M. Ya., \& Lisovyj, M. M. (2015). Rezultaty iniciacii eksplantiv okremyh kultyvariv rodu Picea v umovah in vitro. Suchasni resursozberigayuchi tehnologii. Problemy i perspektyvy: zbirka dopovidei tretyoi Mizhnarodnoyi naukovo-practychnoyi konferenciyi (Ukraina, Odesa: 9-13 lystopada 2015 roku, pp. 175-179), Odesa. [in Ukrainian].

Gozhan, M. Ya., Guz, M. M., \& Grechanyk, R. M. (2012). Osoblyvosti formovogo riznomanittya vydiv rodu Picea. Scientific Bulletin of UNFU, 22(11), 29-36.

Gozhan, M. Ya., Guz, M. M., Grechanyk, R. M., \& Lisovyj, M. M. (2014). Osoblyvosti realizacii etapu iniciacii eksplantiv kultyvariv rodu Picea A. Dietr. in vitro. Scientific Bulletin of UNFU, 24(7), 37-42. [in Ukrainian].

Grechanyk, R. M., Gozhan, M. Ya., \& Guz, M. M. (2012). Osoblyvosti otrymannya aseptychnoi cultury eksplantiv taksoniv rodu Picea A. Dietr. in vitro. Scientific Bulletin of UNFU, 22(14), 18-25. [in Ukrainian].

Grechanyk, R. M., Guz, M. M., \& Oleksiychenko, N. O. (2011). Osoblyvosti vvedennya v kulturu in vitro shovkovyci biloi (Morus alba Linn.). Scientific Bulletin of UNFU, 21(17), 9-21. [in Ukrainian].

Katayeva, N. V., \& Butenko, R. G. (1983). Klonalnoe microrazmnozheniye rastenij. Moscow : Nauka, 96 p. [in Russian].

Kohno, M. A. (Ed.), Gordiyenko, V. I., Zakharenko, G. S., Kuznyecova, S. I. (Ed.), et al. (2001). Dendroflora Ukrainy. Dykorosli ta kultyvovani dereva i kushchi. Golonasinni: dovidnyk; NAN Ukrainy, Nac. bot. sad im. M. M. Gryshka. Kyiv : Vyshcha shkola, 207 p. [in Ukrainian].

Krajtbkovb, J., Bertolini, A., \& Gcmcry, D. (2013). In vitro. Cell. Dev. Biol.-Plant., $560 \mathrm{r}$.

Szczygie, K., Hazubska-Przyby, T., Bojarczuk, K. (2007). Somatic embryogenesis of selected coniferous tree speciesof the genera picea, abiesand larix. Acta Societatis Botanicorum Poloniae, 76(1), $7-15$.

Lebedev, V. G., \& Shestibratov, K. A. (2011). Organogenez sosny obyknovennoi (Pinus sylvestris L.) v culture in vitro. Retrieved from: http://conf. nsc. ru/cfgrs2011/reportview/35573. [in Russian].

Lisovyj, M. M. (2016). Osoblyvosti rozmnozhennya Pinus sylvestris L. v umovah in vitro. Scientific Bulletin of UNFU, 26(8), 123-129. [in Ukrainian].

Lisovyj, M. M., Guz, M. M., \& Kanteruk, O. V. (2012). Polimorfizm Abies alba Mill. Zahyst navkolyshnyoho seredovyshcha. Zbalansovane pryrodokorystuvannya: Materialy pyatoi studentskoi naukovopraktychnoi konferencii (Lviv: 2012 r., pp. 42-44), Lviv: DUONS. [in Ukrainian].

Lisovyj, M. M., Guz, M. M., Mandzyuk, R. I., \& Kanteruk, O. V. (2013). Rozmnozhennya dekoratyvnykh form Abies alba Mill. Shcheplennyam. Scientific Bulletin of UNFU, 23(10), 26-30. [in Ukrainian].

Mo, L. H., \& von Arnold, S. (1991). Origin and Development of Embryogenic Cultures from Seedlings of Norway Spruce (Picea abies). Journal of Plant Physiology, 138(2), 223-230. 
Musiyenko, M. M., \& Panyuta, O. O. (2005). Biotehnologiya roslyn: Kyiv: VPC "Kyivskyi universytet", 114 p. [in Ukrainian].

Nawrot-Chorabik, K. (2008). Embryogenic callus induction and differentiation in silver fir (Abies alba MilL.) tissue cultures. Dendrobiologi, 59, 31-40.

Pokhylchenko, O. P. (2011). Biologicheskie osnovy kultivirovaniya yeley (Picea A. Dietr.) v Ukraine. Kyiv: DGVPP "Zovnishtorgvydav Ukrainy", 138 p. [in Russian].

Pravdin, L. F. (1975). Yel yevropeyskaya i yel sibirskaya. Moscow: Nauka, 176 p. [in Russian].
Shlapak, V. V., \& Nebikov, M. V. (2011). Osoblyvosti nasinnyevogo rozmnozhennya Pinus sylvestris L. v umovah in vitro. Scientific Bulletin of UNFU, 21(14), 43-48. [in Ukrainian].

Szczygiel, K., \& Kowalczyk, J. (2001). Somatic embryogenesis of sylver fir (Abies alba MilL.). Acta Hort. (ISHS), 560, 509-512.

Ziauka, J., \& Kuusienl, S. (2006). Changes in Development of European Larch (Larix decidua MilL.) Vegetative Buds Induced by Plant Hormones. Baltic Forestry, 12(2), 141-150.

\section{ПЕРСПЕКТИВИ ВІДТВОРЕННЯ ГЕНЕТИЧНИХ РЕСУРСІВ ГОЛОВНИХ ЛІСОТВІРНИХ ГОЛОНАСІННИХ ПОРІД УКРАЇНИ РОЗМНОЖЕННЯМ IN VITRO}

Проведено огляд та аналіз літературних джерел, які стосуються розмноження головних хвойних лісотвірних порід України в умовах in vitro, на основі чого зроблено висновок та обгрунтовано доцільність проведення запланованих досліджень. Наведено коротку лісівничу характеристику та господарську цінність найпоширеніших видів: Pinus sylvestris L., Picea abies (L.) Karsten., Abies alba Mill., Larix decidua Mill., як об'єктів досліджень. Подано детальну характеристику застосованої методики проведення експериментальних досліджень 3 мікроклонального розмноження досліджуваних видів: способи стерилізації лабораторних приміщень та потрібного обладнання; перелік хімічних агентів для проведення ступінчастої деконтамінації експлантів; склад модифікованих фітогормонами живильних середовищ для ініціації та укорінення отриманих рослинрегенерантів в умовах in vitro; умови культивування експлантів; схему проведення адаптації клонів до умов ex vitro. Експериментально встановлено: необхідність першочергового обробітку експлантів етанолом для всіх без винятку порід на етапі деконтамінації; внесення до складу живильного середовища як ауксинів, так і цитокінінів на етапі ініціації; позитивний вплив конкретних фітогормонів на укорінення рослин-регенерантів. Узагальнено та проаналізовано отримані результати.

Ключові слова: лісотвірна порода; розмноження; in vitro; експлант; деконтамінація; ініціація; ризогенез; адаптація.

Н. Н. Лисовый, Н. Н. Гузь

Национальный лесотехнический университет Украины, г. Львов, Украина

\section{ПЕРСПЕКТИВЫ ВОСПРОИЗВОДСТВА ГЕНЕТИЧЕСКИХ РЕСУРСОВ ГЛАВНЫХ ЛЕСООБРАЗУЮЩИХ ГОЛОСЕМЕННЫХ ПОРОД УКРАИНЫ РАЗМНОЖЕНИЕМ IN VITRO}

Проведен обзор и анализ литературных источников, касающихся размножения главных хвойных лесообразующих пород Украины в условиях in vitro, на основе чего сделан вывод и обоснована целесообразность проведения запланированных исследований. Приведена краткая характеристика и хозяйственная ценность следующих видов: Pinus sylvestris L., Larix decidua Mill., Abies alba Mill., Picea abies (L.) Karsten., в качестве объектов исследований. Подробно охарактеризована примененная методика проведения экспериментальных исследований по микроклональному размножению исследуемых видов: способы стерилизации лабораторных помещений и необходимого оборудования; список химических агентов для проведения ступенчатой деконтаминации эксплантов; состав модифицированных фитогормонами питательных сред для инициации и укоренения полученных растений-регенерантов в условиях in vitro; условия культивирования эксплантов; схему проведения адаптации клонов к условиям ex vitro. Экспериментально установлено: необходимость первоочередной обработки эксплантов этанолом для всех без исключения пород на этапе деконтаминации; внесение в состав питательной среды как ауксинов, так и цитокининов на этапе инициации; положительное влияние конкретных фитогормонов на укоренение растений-регенерантов. Обобщены и проанализированы полученные результаты.

Ключевые слова: лесообразующая порода; размножение; in vitro; эксплант; деконтаминация; инициация; ризогенез; адаптация. 